\title{
Marcin Mironowicz
}

BIAtOSTOCKIE

TEKI

HISTORYCZNE

TOM 15/2017

ISSN 1425-1930

Wydział Historyczno-Socjologiczny

Uniwersytet w Białymstoku

DOI: $10.15290 /$ bth.2017.15.05

\section{Spór o genezę bractw cerkiewnych w literaturze historycznej ${ }^{1}$}

Bractwa cerkiewne pojawiły się na terenie Wielkiego Księstwa Litewskiego nieprzypadkowo, a były efektem określonej sytuacji społeczno-religijnej. W drugiej połowie XV w. zmieniły się relacje wyznaniowe w miastach Wielkiego Księstwa Litewskiego i na ziemiach ruskich Korony. W 1434 r. na terenie ziemi halickiej i na Podolu zostało zniesione dawne prawo ruskie, a na jego miejsce wprowadzone zostało prawodawstwo polskie. Zmiany te dotyczyły również prawnego usytuowania cechów rzemieślniczych. Na ziemiach ruskich Korony mieszczanie prawosławni byli odsuwani od uczestnictwa we władzach miejskich. Po raz pierwszy doszło do konfliktów wyznaniowych w cechach rzemieślniczych na terenie miast o zróżnicowanej strukturze wyznaniowej. W obronie interesów ekonomicznych, narodowych i religijnych ludności prawosławnej powstały bractwa cerkiewne ${ }^{2}$.

Bractwa jako forma życia społeczno-religijnego pojawiło się już w IV stuleciu na terenie Konstantynopola i Egiptu. Organizacje te zajmowały się usługami pogrzebowymi, utrzymywaniem cmentarzy, opieką na chorymi, propagowaniem kultu i praktyk religijnych ${ }^{3}$. Z czasem bractwa stały się jedną $\mathrm{z}$ form życia to-

\footnotetext{
1 Praca naukowa finansowana ze środków budżetowych na naukę w latach 2015-2018 jako projekt badawczy w ramach programu pod nazwą „Diamentowy Grant”.

2 K. Chodynicki, Kościót prawosławny a Rzeczpospolita Polska. Zarys historyczny 1370-1632, Warszawa 1934, s. 90, 91; J. Woliński, Polska i Kościót prawosławny. Zarys historyczny, Lwów 1936, s. 24, 25; A. Podraza, Dzieje ziem ukraińskich do 1569 r., [w:] Ukraina. Teraźniejszość i przeszłość, red. A. Podraza, Kraków 1970, s. 250, 251; A. Mironowicz, Kościót prawostawny w państwie Piastów i Jagiellonów, Białystok 2003, s. 191, 231-233.

3 E. Wipszycka, Świeckie bractwa w życiu religijnym chrześcijańskiego Egiptu, „Przegląd Historyczny” 1968, R. LIX, z. 3, s. 447-462; J. Kłoczowski, Wspólnoty chrześcijańskie. Grupy życia wspólnego w chrześcijaństwie zachodnim od starożytności do XV w., Warszawa 1964, s. 238-239; S. Litak, Bractwa religijne w Polsce przedrozbiorowej XIII-XVIII wiek. Rozwój i problematyka, „Przegląd Historyczny” 1997, t. 88, z. 3-4, s. 500-501; S. Dmitruk, Teorie naukowe dotyczące powstania bractw cerkiewnych na terenie Rzeczypospolitej Obojga Narodów w XV-XVI wieku, „Wschód Europy” 2015, nr 1(2), s. 50-53.
} 
warzyskiego. Rozwój konfraterni skupiających świeckich nastąpił w średniowieczu wraz z potrzebą krzewienia pobożności, prowadzenia szpitali i przytułków oraz działalnością społeczno-gospodarcza klasztorów. Masowy ruch zakładania świeckich organizacji religijnych w Kościele katolickim nastąpił dopiero w okresie kontrreformacji ${ }^{4}$.

Pochodzenie bractw cerkiewnych nie jest do końca wyjaśnione. Wokół genezy tego specyficznego zrzeszenia wiernych wyznania prawosławnego na ziemiach Wielkiego Księstwa Litewskiego trwała w historiografii burzliwa dyskusja ${ }^{5}$. Kluczowym pytaniem pozostaje, czy bractwa uformowały się opierając się na zachodnioeuropejskim modelu stowarzyszeń, czy ukształtowały się one w przeszłości wśród społeczności słowiańskich? Niektórzy historycy odnoszą ideę powstania bractwa do okresu pogańskiego, kiedy funkcjonowały jeszcze silne związki rodowe. Według Mikołaja Hruszewskiego, grecka „fratria” to nic innego, jak południowosłowiańskie „bractwo”. Według tej teorii, w Europie Zachodniej więzy rodowe przekształciły się w cechy lub zawodowe organizacje nazwane bractwami (fraternia).

W społeczeństwie wschodniosłowiańskim związki rodowe ewaluowały w związki rodowo-terytorialne, przyjmując nazwę bractw. Z czasem organizacje te nabierały charakteru religijnego (szacunek do szczególnie czczonych patronów,

\footnotetext{
4 B. Kumor, Kościelne stowarzyszenia świeckich na ziemiach polskich w okresie przedrozbiorowym, „Prawo Kanoniczne” 1967, t. X, nr 1-2, s. 289-356; B. Lorens, Bractwa cerkiewne w eparchii przemyskiej w XVII i XVIII wieku, Rzeszów 2005, s. 29.
}

5 Poglądy historyków na temat genezy bractw cerkiewnych por.: Макарий (Булгаков), митр., История Русской Церкви, т. IX, кн. 4, Санкт-Петербург 1879, с. 469, 509, 510; Я. Д. Ісаєвич, Братства та їх роль в розвитку української культури XVI-XVIII ст., Київ 1966, с. 37-40; L. Bieńkowski, Organizacja Kościoła wschodniego w Polsce, [w:] Kościót w Polsce. Studia nad historiq Kościoła katolickiego w Polsce, red. J. Kłoczowski, t. II, cz. 2, Kraków 1969, s. 832; A. Mir ronowicz, Geneza bractw cerkiewnych, „Białoruskie Zeszyty Historyczne” 1996, nr 2 (6), s. 22-30; idem, Bractwa cerkiewne w Rzeczypospolitej, Białystok 2003, s. 11-16; B. Lorens, op. cit., s. 28-40; С. С. Лукашова, Движение православных братств на украинско-белорусских землях в последней четверти XVI в., [в:] Тезисы доклада на V Международном конгрессе украинистов, Черновцы 2002; idem, Миряне и Церковь: религиозные братства киевской митрополии в к оние XVI в., Москова 2006, с. 6-40; О. А. Фефелова, Православные братства на осточнославянских территориях Речи Посполитой во второй половине XVI - первой половине XVII веков, Оглавление научной работы автор диссертации - кандидата исторических наук Фефелова Оксана Анатольевна, Томск 2001; idem, Исторические источники по истории правоставных братств на территории Беларуси во второй половине XVI - первой половине XVII века, „Вестник ТГПУ”, 2010, Вып. 9 (99); S. Dmitruk, Teorie naukowe dotyczące powstania bractw cerkiewnych na terenie Rzeczypospolitej Obojga Narodów w XV-XVI wieku, s. 45-56; Д. А. Вeликжанин, Религиозно-оборонительные братства Украины о Белоруссии кониа XVI- первой половины XVII вв. как институты православной иеркви, „Научные проблемы гуманитарных исследований”, № 9, 2010, с. 27-30; Ф. А. Дорофеев, Правоставные братства: генезис, эволюиия, современное состояние, Нижний Новгород 2006.

6 М. Грушевський, Історія України-Руси, т. VI: Житє економічне, культурне, національне XIV-XVII віків, Київ - Львів 1907, с. 500. 
uroczyste obchodzenie świąt związanych z tradycją rodową). Cerkiew w tym wypadku stanowiła centrum związku religijnego. Przy świątyni w XII-XIII stuleciu członkom bractwa urządzano kilka razy do roku uroczyste uczty, najczęściej w dni świąt patronalnych. Z okazji uczt - bratczyn - warzono piwo i sycono miód, który był następnie sprzedawany. Na rozwój bractw wpływ miały organizacje cechowe, rozwijające się na terenie Rzeczypospolitej wraz z upowszechnieniem prawa magdeburskiego. Według Mikołaja Hruszewskiego, w drugiej połowie XV w. organizacje brackie poddane były silnym wpływom cechów rzemieślniczych. Cechy wyrastały $\mathrm{z}$ tego samego korzenia co bractwa, a ich struktura wewnętrzna była zbliżona do organizacji brackich. Ustawy bractw miodowych były podobne do statutów cechowych. W wielu bractwach cerkiewnych wprowadzono zwyczaje cechowe: sposób wyboru władz, organizacja sądu brackiego, uroczyste ceremonie pogrzebowe, organizowanie wspólnych uczt, sycenie miodu. Cechy rzemieślnicze w wielu przypadkach stały się podstawą funkcjonowania bractw cerkiewnych. Z kręgu społeczeństwa cechowego rekrutowała się największa liczba członków bractw$^{7}$.

Mikołaj Hruszewski uważał bractwa cerkiewne za stowarzyszenia słowiańskie, które były odpowiedzią na potrzeby miejscowej społeczności. Według tego badacza bractwa działały opierając się na ustroju cerkiewnym, który gwarantował świeckim wpływ na życie wewnętrzne swojego Kościoła. Soborowość w Cerkwi wschodniej wyrażała się m.in. w tworzeniu organizacji religijnych takich, jak bractwa cerkiewne. Sytuacja wewnętrzna w Cerkwi prawosławnej w Rzeczypospolitej sprzyjała tym procesom ${ }^{8}$.

Aleksander Papkow łączył powstanie bractw cerkiewnych z organizacjami parafialnymi i z dawnymi bractwami miodowymi. Pierwsze bractwa miodowe powstały przy świątyniach. Zgodnie ze starym zwyczajem w czasie głównych świąt cerkiewnych bractwa wyrabiały świece, warzyły piwo, syciły miód i ustawiały „piry” (uczty), z których dochód był przeznaczony na potrzeby cerkwi ${ }^{9}$. Podobny pogląd na temat powstania bractw wyrazili inni historycy tego okresu Fiodor

\footnotetext{
7 Ibidem, c. 501-503.

8 М. Грушевський, Історія України-Руси, т. VI, с. 505-507; idem, Iсторія української літератури, Київ, 1995, т. V, кн. 2. с. 311-317.

9 А. А. Папков, Братства. Очерки истории западно-русских православных братств, Сергиев Посад 1900, c. LV-LXIV; idem, Церковные братства. Краткий статистический очерк о положении иерковных братств к началу 1893 года, Санкт-Петербург 1893; idem, Братства как мощзная защита Православия - вплоть до восстановления православной иерархии в 1620 году (1600-1620), „Богословский вестник”, - январь, Сергиев Посад 1898; idem, Древнерусский приход, „Богословский вестник”, ч. III, № 2. - Сергиев Посад 1897; idem, Начало возрождения церковно-приходской жизни в России, Отдельный оттиск из журнала “Русский Вестник”, Москва 1900.
} 
Żudro $^{10}$ i Władysław Łuksza ${ }^{11}$. Ten ostatni wszystkie cztery bractwa działające w Wilnie nazywał „miodowymi”. Również Józef Morzy podkreślał, że wileńskie „bractwa miodowe powstawały przy cerkwiach i grupowały głównie ludzi wyznania prawosławnego"12.

Metropolita Makary [Bułhakow] w swej fundamentalnej wielotomowej pracy История русской иеркви wskazywał, że bractwa cerkiewne były zreformowaną formą bractw miodowych. Musiały one powstać z uwagi na zmianę prawnego położenia wyznawców prawosławia na ziemiach ruskich Rzeczypospolitej. Nowe bractwa nie mogły koncentrować się jedynie na sprawach wewnętrznych swojej organizacji ale zająć się podstawowymi problemami ówczesnej Cerkwi: obrony swej wiary przed propagandą jezuitów poprzez szkolnictwo, edukację, naukę i upowszechnienie nauki św. Ojców Kościoła ${ }^{13}$. Zewnętrzne podobieństwo bractw z katolickimi organizacjami metropolita Makary wyjaśniał kryzysem prawosławnej teologii i życia duchowego ${ }^{14}$.

Według Sergiusza Sołowiowa, bractwa powstały z bratczin, organizacji wywodzących się ze związków rzemieślniczych Nowogrodu i Pskowa. Historyk wiązał genezę bractw cerkiewnych $\mathrm{z}$ wprowadzeniem na ziemiach ruskich chrześcijaństwa i zakładaniem szkół duchownych ${ }^{15}$.

Nikołaj Jefimienko udowadniał, że bractwa cerkiewne były rozwinięciem starosłowiańskich bractw rodowych. Autor rozpatrywał konfraternie jako ostatni etap procesu rozwojowego: $\mathrm{z}$ bractw rodowych, poprzez gildie, bractwa rzemieślników do bractw cerkiewnych. Z kolei Aleksandra Jefimienko wprowadziła pojęcie ,dobrowolnego rodu”. Prototypem bractw były organizacje rodowe. Według tej teorii bractwa nie powstały z chwilą wydania dokumentu (aktu) mówiącego o ich powołaniu, lecz istniały wraz z pojawieniem się wspólnoty wyznaniowej, w której one funkcjonowały ${ }^{16}$. Bractwa powstały w odległej przeszłości

\footnotetext{
10 Ф. Жудро, История Могилевского Богоявленского братства, Могилев 1890.

11 W. Łuksza, W sprawie prawosławnych bractw miodowych $w$ Wilnie, „Atheneum Wileńskie” 1938, t. XIII, z. 2, s. 288-290.

12 J. Morzy, Geneza i rozwój cechów wileńskich do końca XVII w., „Zeszyty Naukowe Uniwersytetu Adama Mickiewicza", Seria Historia, z. IV, Poznań 1959, s. 11.

13 Макарий (Булгаков), митр., История русской церкви, Кн. 5, Период разделения Русской Церкви на две митрополии. История Западнорусской, или Литовской, митрополии (14581596). Научн. Ред. Б. Н. Флоря, Москва 1996, s. 417, 614-615.

14 Макарий (Булгаков), митр., История Русской Церкви, т. ХІ, Санкт-Петербург 1882, с. 410, 482 .

15 С. М. Соловьев, Братчины, „Русская беседа”, кн. IV, 1856, с. 108-117; М. Грушевський, Iсторія України-Руси, т.VI, с. 632; A. Mironowicz, Geneza bractw cerkiewnych, s. 23.

16 П. Ефименко, Братства и союзы нищих, „Киевская старина”, т. VII, Киев 1883, нр. 9, c. $277,316-317$.
} 
opierając się na organizacjach rodowych, stanowiących religijno-społeczne tło funkcjonowania zbiorowości ${ }^{17}$.

XIX-wieczni historycy rosyjscy uważali, że bractwa nie były organizacjami oryginalnymi, a bezpośrednio kontynuowały zadania ruskich starych bratczin. Takie założenie nie uwzględniło odmiennych warunków funkcjonowania wspólnot wyznaniowych w Rusi północno-wschodniej i Wielkim Księstwie Litewskim. Bractwa na terenie Rzeczypospolitej poza celami kulturalno-oświatowymi zajmowały się obroną interesów prawosławia i narodowości ruskiej. Konfraternie cerkiewne nie miały podobieństwa do zachodnioeuropejskich cechów, albowiem na pierwszy plan wysuwały sprawy religijno-narodowe i działalność oświatową. Bratcziny w Rusi północnej nie pełniły podobnych zadan. Wreszcie staroruskie bratcziny funkcjonowały w XII i XIII w., a pierwsze bractwa na ziemiach Wielkiego Księstwa Litewskiego powstały w połowie XV i rozwinęły się w XVI i XVII stuleciu w okresie konfliktów wyznaniowych ${ }^{18}$.

Podobnie Aleksander Łotocki wiązał genezę bractw cerkiewnych ze starym zwyczajem bratczin, praktykowanym w chrześcijaństwie wschodnim. Tego zwyczaju nie było na Rusi Moskiewskiej, ale był praktykowany na terenie ziem ruskich Wielkiego Księstwa Litewskiego. Bractwa w opinii ukraińskiego historyka miały podwójny charakter: religijny i cechowy ${ }^{19}$. Podobny pogląd prezentował Michał Opoka. Według niego bractwa miały charakter rodowy a ich członkowie troszczyli się o cerkiew i jej wyposażenie, sycili miód na uczty. W ich działalności można było dostrzec wpływy ruchu reformacyjnego i wzrostu znaczenia mieszczaństwa ${ }^{20}$. Również Włodzimierz Figol uważał, że bractwa cerkiewne to instytucje związane $\mathrm{z}$ tradycją staroruską ale na ich genezę nie miały wpływu zachodnioeuropejskie organizacje religijne. Autor opracowania dowodził, że słowo bractwo oznaczało w tradycji ruskiej rodzinę ${ }^{21}$. Z owym poglądem zgadzali się Krystyna Kuźmiak i Mirosław Szegda, którzy genezę bractw widzieli w bratczinach i biesiadach z okazji wielkich świąt cerkiewnych. Bratcziny przekształciły się w bractwa miodowe, a te pod wpływem organizacji cechowych w organizacje religijne broniące interesów ekonomicznych i narodowych ludności ruskiej ${ }^{22}$.

17 А. Я. Ефименко, Южно-русские церковные братства, „Слово” 1880, нр. 10-12, с. 67-104, 235.

18 А. Я. Ефименко, Южно-русские братства, [в:] Южная Русь (Очерки, исследования, заметки), т. І, Санкт-Петербург 1905, с. 200-309.

19 А. Лотоцький, Украінські джерела церковного права, Варшава 1931, с. 187-188.

20 M. Opoka, Prawostawne bractwa na Rusi, „Oriens” 1938, R. VI, s. 114-115.

21 В. Фіґоль, Церковні братства галицької греко-католицької провінції у XVIII cm., „Богословія", т. XV, Рим 1937, с. 92-93. Por. również idem, с. 91-101, 243-252; т. XVI, 1938, с. 31-39, 137-157, 215-232.

22 K. Kuźmiak, M. Szegda, Cerkiewne bractwo, [w:] Encyklopedia Katolicka, t. III, Lublin 1985, szp. 13-14; B. Lorens, Bractwa cerkiewne w eparchii przemyskiej w XVII i XVIII wieku, s. 28. 
Ku tej teorii skłaniała się również Swietłana Łukaszukowa, autorka monografii o roli świeckich w życiu Cerkwi. Według rosyjskiej badaczki wywodzące się z bractw miodowych bractwa cerkiewne były głównym obrońcą praw ludności ruskiej wyznania prawosławnego ${ }^{23}$. Po analizie historiografii na temat genezy bractw cerkiewnych Swietłana Łukaszukowa stwierdziła, że nie jest w stanie wskazać jednoznacznie na prototypy bractw cerkiewnych z końca XVI w. Badaczka zwróciła uwagę na ich wspólne cechy z religijnymi organizacjami katolickimi występującymi na ziemiach ruskich Rzeczypospolitej. Problem ten oraz wzajemne relacje bractw z hierachią cerkiewną wymagał w jej opini szczegółowej analizy. Jej postulatem badawczym pozostaje porównanie brackiej ideologii z prawosławną i protestancką tradycją reform oraz analiza specyfiki działalności konfraterni w wielu płaszczyznach ich aktywności ${ }^{24}$. Podobną opinię o genezie i roli bractw przedstawiła Julia Szustowa i Oksana Fefełowa ${ }^{25}$.

Zupełnie oryginalną koncepcję o pochodzeniu bractw przedstawił Michaił Dimitrew, który dopatrywał się ich źródła w specyficznej ,prawosławnej świadomości”, ukształtowanej w tradycji wschodnio-chrześcijańskiej oraz w kryzysie w relacjach między duchowieństwem a świeckimi. Charakterystyczna świadomość wyznawców prawosławia kontrastowała w opinii moskiewskiego badacza z tradycyjnym światopoglądem ukształtowanym w kręgu chrześcijaństwa zachodniego ${ }^{26}$. Źródła do dziejów bractw cerkiewnych nie dają podstaw do sformułowania takiego wniosku.

23 С. С. Лукашова, Движение православных братств на украинско-белорусских землях в последней четверти XVI в., [в:] Тезисы доклада на V Международном конгрессе украинистов, Черновцы 2002; eadem, Миряне и Церковь: религиозные братства киевской митрополии в $к$ онце XVI в., Москва 2006; еadem, Мифы и стереотипы в историографии украинско-белорусских братств XVI-XVII вв. [в:] Между Москвой, Киевом и Варшавой, Москва 2008.

24 С. С. Лукашова, Миряне и Церковь: религиозные братства киевской митрополии в коние $X V I$ в., c. 26.

25 Ю. Э. Шустова, Типология происхождения братств Украинь, [в:] Историко-филологический вестник Украинского Института, т. I, Москва 1997. с. 113-116; еadem, Українські братства як провідники діяльної релігійності в кінці XVI і на початку XVII cm., [в:] Iсторія релігій в Україні: Матеріали VIII міжнародного круглого столу, Львів 1998, с. 291-293; О. А. Фефе8 лова, Правоставные братства..; eadem, Исторические источники по истории православных братств на территории Беларуси во второй половине XVI - первой половине XVII века, „Вестник ТГПУ” 2010, Вып. 9 (99).

26 М. В. Дмитриев, Между Римом и Царьградом: генезис Брестской церковной унии 1595-1596 22., Москва 2003, с. 283; idem, Религиозно-культурная и социальная программа греко-католической церкви в Речи Посполитой в конце XVI первой половине XVII в., [в:] Славяне и их соседи. Католииизм и православие в Средние века, Москва 1991, с. 66-68, 76-96; idem, Кониепиії унії в иерковних і державних колах Речі Посполитої кіния XVI cm., [в:] Історичний контекст укладення унї і перше поунійне покоління: Матеріали Перших Берестейських читань, Львів 1995, с. 39-73. Podobny pogląd zaprezentował Sergiusz Jakowenko, por.: С. Г. Яковенко, Православная иерархия Речи Посполитой и планы церковной унии в 1590-1594 г2. [в:] „Славяне и их соседи”, вып. 3, Католицизм и православие в средние века, Москва 1991, с. 41-59. 
Zwolennikiem poglądu, że bractwa cerkiewne powstały pod wpływem podobnych stowarzyszeń funkcjonujących w Kościele łacińskim, był Edward Likowski. Jego zdaniem w Cerkwi prawosławnej nie znano tego typu organizacji i dopiero w XV stuleciu po zetknięciu się z zachodnim chrześcijaństwem bractwa takie mogły powstać. Rozwój bractw, a co za tym idzie i zwiększenie się udziału świeckich w życiu Cerkwi, nastąpił z podjęciem w niej reform wewnętrznych, po upadku hierarchii ${ }^{27}$. Badacz ten całkowicie zignorował: cele i formy działalności bractw, cerkiewne prawo ustrojowe i tradycję staroruską. Pogląd E. Likowskiego nie ma też źródłowego uzasadnia. Mimo to historycy katolicy podzielali opinie, że bractwa cerkiewne rozwijały się pod wpływem kontaktów z Kościołem łacińskim. Izydor Szaraniewicz stwierdził nawet, że ,instytucja bractw cerkiewnych była obca Kościołowi wschodniemu. Kościół ten nie znał i nie zna ich dotąd. Na Rusi zaczęły się one przecież zawiązywać przy niektórych cerkwiach osobliwie klasztornych, przez naśladownictwo Kościoła łacińskiego około połowy XV wieku"28. Ze współczesnych historyków opowiada się za poglądem Edwarda Likowskiego Henryk Samsonowicz, który udowadniał, że bractwa cerkiewne powstały pod wpływem wzorców zachodnich płynących z ziem polskich. Głównym uzasadnieniem jego opinii był fakt, że bractwa nie występowały na terenie Rusi Kijowskiej i w Księstwie Moskiewskim. Według tego badacza zasadniczy wpływ na rozwój bractw miała sytuacja ekonomiczno-polityczna mieszczaństwa ruskiego. Ruchy zmierzające do zmiany porządku społecznego, łączyły się z postulatami obrony wiary i reformy Cerkwi prawosławnej ${ }^{29}$. Z kolei Alina Nowicka-Jeżowa w charakterystyczny dla polskiej historiografii sposób stwierdziła, że bractwa powołane przez patriarchów do kontroli duchowieństwa i biskupów podjęły się również ożywienia intelektualé nego i odrodzenia szkolnictwa. Obok pozytywnych elementów aktywności bractw autorka opracowania wskazała na negatywne strony ich funkcjonowania, takie jak wywołanie przez nie konfliktów wewnętrznych w Cerkwi i obniżenie prestiżu hierarchii ${ }^{30}$.

Kompromisowe stanowisko zajął Kazimierz Chodynicki, który widział genezę bractw cerkiewnych w instytucjach cerkiewnych już w IV w. Badacz doceniał

27 E. Likowski, Unia brzeska (r. 1596), Poznań 1896, s. 62-63.

28 I. Szaraniewicz, Kościelna Unia na Rusi i wptyw jej na zmianę stanowiska społecznego świeckiego duchowieństwa ruskiego, [w:] Księga pamiątkowa drugiego Wiecu Katolickiego odbytego we Lwowie w dniach 7, 8 i 9 lipca 1896 roku. Część I, Lwów 1899, s. 17; idem, Patryjarchat wschodni wobec Kościoła ruskiego i Rzeczypospolitej Polskiej, Lwów 1879; J. Bartoszewicz, Szkic dziejów kościoła ruskiego w Polsce, Kraków 1880, s. 141.

29 H. Samsonowicz, Mieszczaństwo Rzeczypospolitej wobec Unii Brzeskiej, [w:] Unia brzeska z perspektywy czterech stuleci, red. J. S. Gajek, S. Nabywaniec, Lublin 1998, s. 78-79.

30 А. Новицкая-Ежова, Орден базилиан и его культурно-просветительская деятельность на украчно-белорусско-литовских землях Речи Посполитой, „Славяноведение”, № 2, 1996, c. 34 . 
wpływ na ich powstanie zachodnioeuropejskich cechów rzemieślniczych. Samo pojęcie konfraterni według Chodynickiego znane było w Cerkwi prawosławnej i pojawiło w okresie niepodzielonego chrześcijaństwa. Rozwój stowarzyszeń cerkiewnych nastąpił wraz ze wzrostem znaczenia organizacji cechowych w Rzeczypospolitej ${ }^{31}$. Podobnie współczesny badacz Borys Gudziak uważał, że bractwa cerkiewne zostały oparte o wzorce zachodnie, zwłaszcza o cechy rzemieślnicze, niezależnie od wpływu na nie dawnej tradycji ruskiej. Konieczność ochrony własnych interesów wiązała się z obroną praw Cerkwi i wymagała od stowarzyszeń cerkiewnych wszechstronnych form aktywności (w tym oświatowej i charytatywnej). Program reform bractw przybrał formę ideologii ruchów protestanckich ${ }^{32}$. Wpływ ruchu protestanckiego na genezę bractw dostrzegała Sofia Senyk ${ }^{33}$.

Z kolei Orest Lewicki udowadniał, że instytucje brackie powstały jako egzemplifikacja wpływu elementu świeckiego na sprawy cerkiewne ${ }^{34}$. Autor doceniał kwestie ustrojowe w Cerkwi a zwłaszcza „soborowość” ale dostrzegał również w bractwach wpływ zachodnioeuropejskiego ruchu reformacyjnego i reformatorskiego. Bractwa - w jego opinii - powstały jako odpowiedź elit prawosławnych na politykę kurii rzymskiej na ziemiach białoruskich i ukraińskich ${ }^{35}$. Podobny osąd wyraził historyk ukraiński Sergiusz Płochij ${ }^{36}$.

Odmienny pogląd zaprezentował Iwan Flerow, który genezę bractw na ziemiach litewsko-białoruskich interpretował jako powstanie nowych organizacji

31 K. Chodynicki, Kościót prawosławny a Rzeczpospolita Polska. Zarys historyczny 1370-1632, Warszawa 1934, s. 179.

32 Б. Гудзяк, Царгородський nатріархат у кіниі XVI ст.: криза і спроби реборм, [в:] Пробчи́vүна. Історичні та філологічні розвідки, присвячені 60-річчю академіка Ярослава Ісаєвича, Укл. Б. Якимович, Львів 1998, с. 189-204; idem, Киевская иерархия, Константинопольский патриархат и уния с Римом, [в:] 400 лет Брестской иерковной унии (1596-1996): Критическая переоченка. Сборник материалов международного симпозиума. Неймеген, Голландия, Москва 1998, с. 29-59; idem, Криза і реформа. Київська митрополія, Царгородський nатріархат і генеза Берестейскої унії, Львів 2000, с. 190-192, 216-217. Ten sam pogląd o gee nezie bractw wyraził Wasyl Luciw, który upatrywał ich początki rodowych organizacjach słowiańe skich oraz zachodnioeuropejskich gildiach i cechach kupieckich. В. Луців, Церковні братства в Україні, „Богословия”, Рим 1973, с. 89-123.

33 С. Сенык, Брестская уния: подведение итогов, [в:] 400 лет Брестской церковной унии (1596-1996): Критическая переоценка: Сборник материалов международного симпозиума, Неймеген, Голландия, Москва 1998, с. 16.

34 О. И. Левицкий, Внутреннее состояние западно-русской иеркви в польско-литовском государстве в конце XVI в. и уния, Киев 1884, с. 15.

35 О. И. Левицкий, Социнианство в Польше и Юго-Западной Руси [в:] „Киевская Старина”, m. II, 1882, с. 25-27, 193-224, 401-432.

36 С. Н. Плохий, Папство и Украина: политика римской курии на украинских землях в XVIXVII вв., Киев 1989. 
cerkiewnych, rozwiniętych pod wpływem prawa magdeburskiego ${ }^{37}$. Według Flerowa, ,mieszczanie danego miasta, przyjmujący prawo magdeburskie, otrzymywali wewnętrzne prawa, swoje sądy i urzędy. Władza administracyjna należała do burmistrzów i rajców, sądowa zaś do wójtów, ławników i sędziów. Rzemieślnicy byli skupieni w cechach. Cechy tworzyły korporacje, posiadające własną regułę, struktury i władzę. Rzemieślników jednego cechu nazywano bractwem. Bractwo cechowe posiadało własną cerkiew, na której utrzymanie łożyło środki pieniężne (...). Cechy i bractwa cerkiewne posiadały wiele elementów wspólnych: wspólny zarząd, własny sąd, coroczne wybieranie czterech braci do kierowania sprawami brackimi, wspólny skarb, do którego wpływały pieniądze. Bractwa cechowe i cerkiewne posiadały podobne obowiązki wobec swych członków (pomoc chorym, rodzinom zmarłych)" ${ }^{\prime 3}$. Flerow w swym porównaniu nie zauważał podstawowej różnicy między bractwami a cechami. Cechy oprócz spraw rzemieślniczych posiadały jedynie częściowo religijny charakter, podczas gdy bractwa cerkiewne miały niemal wyłącznie konfesyjne oblicze swej działalności.

Podobnie Mikołaj Kojałowicz udowodniał, że bractwa powstały w oparciu o cechy miejskie, składające się z rzemieślników tej samej branży ${ }^{39}$. Zadaniem ich była obrona interesów grupy rzemieślniczej. Z czasem samodzielne organizacje cechowe tworzyły zamknięte struktury, które odgrywały ważną rolę w życiu społeczno-politycznym miasta. W historiografii polskiej porównaniem rozwoju bractw z organizacjami cechowymi zajmował się Jan Ptaśnik. W miastach o zróżnicowanej strukturze wyznaniowej statuty cechowe faworyzowały katolików. Rzadko panowały w nich stosunki tolerancyjne ${ }^{40}$. Cechy były w zasadzie instytucjami katolickimi, chociaż należeli do nich wyznawcy innych wyznań chrześcijańskich. $\mathrm{W}$ ich wewnętrznej strukturze uprzywilejowane stanowiska zajmowali katolicy. System ten powodował narastanie nietolerancji wyznaniowej wewnątrz cechów ${ }^{41}$. Był to dodatkowy impuls do tworzenia przez prawosławnych organizacji zawodowych o charakterze religijnym.

Mikołaj Skabałanowicz poszedł dalej w ocenie wpływu prawa magdeburskiego na rozwój bractw. W ich rozwoju historycznym badacz wyróżniał trzy główne okresy: 1) w początkowej fazie rozwoju bractwa stanowiły odmianę gildii z tą różnicą, iż ich działalność nie miała tak wykrystalizowanego charakteru jak gildie, a głównie skoncentrowana była na potrzebach Cerkwi, stąd też ich późniejsza

\footnotetext{
37 И. О. Флеров, О правоставных иерковных братствах, противодействовавших унии в Юго-Западной России в XVI, XVII и XVIII cm., Санкт-Петербург 1857, с. 14-16.

38 Ibidem, c. 15.

39 М. О. Коялович, Чтение о церковных западнорусских братствах, „День” 1862, № 36, с. 5; № 37-42; A. Mironowicz, Bractwa cerkiewne w Rzeczypospolitej, s. 13.

40 J. Ptaśnik, Miasta i mieszczaństwo w dawnej Polsce, Warszawa 1949, s. 124, 125.

${ }^{41}$ J. Morzy, Geneza i rozwój cechów wileńskich do końca XVII w., s. 33.
} 
nazwa „bractwa cerkiewne”. Tego typu bractwa funkcjonowały w XV w., a większego znaczenia nabrały w następnym stuleciu ${ }^{42}$; 2) w II połowie XVI i XVII w. w bractwach cerkiewnych kształtowały się cele pozareligijne. Ich działalność przyjęła charakter obronno-religijny (autor nawiązuje tu do działań obronnych gildii) ${ }^{43}$; 3) w XVII i XVIII w. powstawały bractwa o obliczu kupiecko-rzemieślniczym, które poza celami religijnymi prowadziły sprawy handlowe i rzemieślnicze ${ }^{44}$.

Z kolei Stiepan Gołubiew uważał, że bractwa rozwijały się opierając się na prawie patronatu, funkcjonującego w XV-XVII w. na terenie Rzeczypospolitej. W dobrach szlacheckich patronat był jednoosobowy. W miastach rządzących się prawem magdeburskim opiekunami cerkwi pozostawali sami mieszczanie. Cerkiewne bractwa - według S. Gołubiewa - to nic innego jak rozwijające się pod kolektywnym patronatem (ktitorstwem) związki religijne ${ }^{45}$. Wypada zaznaczyć, że specyficzne związki religijne zrzeszały przeważnie grupę ludzi o jednakowych zainteresowaniach i najczęściej wykonujących tę samą pracę. Pogląd ten wydobywa na pierwszy plan element cerkiewnej działalności bractw, pomijając inne formy aktywności (politycznej, społecznej, kulturalnej). Rada miejska i wójt mieli niewielki wpływ na zarząd bractwa, pomimo że sprawowały patronat nad lokalną cerkwią ${ }^{46}$.

Zachodniej koncepcji genezy bractw bronił Nikołaj Suworow. Według niego instytucje brackie przybyły z Europy Zachodniej i podobnie jak Iwan Flerow interpretował powstanie bractw na ziemiach litewsko-białoruskich jako powstanie nowych organizacji cerkiewnych rozwiniętych pod wpływem prawa magdeburskiego ${ }^{47}$. Obaj w swym porównaniu nie dostrzegali podstawowych różnic między bractwami a cechami. Na inne przyczyny powstania bractw cerkiewnych zwrócił uwage Mikołaj Pokrowski. Według tego historyka bractwa były organizacjami miejskiej burżuazji walczącej z feudałami o dominującą pozycję w mieście. Głównym powodem tworzenia bractw były interesy ekonomiczne i społeczne ich członków ${ }^{48}$. Oficjalna wykładnia historiograficzna przyjęta w pewnych momentach

\footnotetext{
42 Н. Скабаланович, Западно-Европейские гильдии и западно-русские братства, „Христианское чтение”, ч. II, 1875, №№ 9-10, с. 290-313.

43 Ibidem, c. 313-319.

44 Ibidem, c. 319-327.

45 С. Т. Голубев, О первых временах Киево-Богоявленского братства и школы при нем, „Труды Киевской Духовной Академии", № 3, 1882, с. 233-254; idem, История Киевской Духовной Академии, вып. 1: Период до-могилянский, Киев 1886, с. 79-83.

46 A. Mironowicz, Bractwa cerkiewne w Rzeczypospolitej, s. 11.

47 Н. С. Суворов, Учебник иерковного права, Москва 1913, с. 116, 117; И. О. Флеров, О православных церковных братствах, с. 14.

48 Mikołaj Pokrowski w pierwszych latach istnienia ZSRR widział działalność bractw jako element walki klasowej. М. Н. Покровский, Русская история с древнейших времен, т. II, Москва 1926, с. 154; т. III, Москва 1913, с. 31-34.
} 
dziejowych w niektórych państwach miała wpływ na to, jak pisano na temat bractw cerkiewnych. W tych przypadkach widoczny jest wpływ ideologii na prezentowane w publikacjach poglądy, bez wyciągania konkretnych wniosków.

Analizując zagadnienie genezy bractw należy podnieść problem roli elementu świeckiego w Cerkwi prawosławnej. W dawnej Rzeczypospolitej patronat nad poszczególnymi parafiami wiejskimi sprawowali właściciele majątków, a w miastach - mieszczanie, od schyłku XVI w. zorganizowani w bractwa cerkiewne. Udział świeckich w sprawowaniu opieki nad Cerkwią nie wynikał z idei ruchu reformacyjnego, ale z tradycyjnej dla Kościoła wschodniego ,soborowości”. Praktyka taka nie była zwyczajem, a prawem ustrojowym Cerkwi, na co zwrócił uwagę Wiaczesław Zaikin ${ }^{49}$. Cechą charakterystyczną podejścia rosyjskiej historiografii z końca XIX w. był jej konfesyjny charakter. Ogólną cechą licznych publikacji tego czasu było udowodnienie tezy, że bractwa powstały do obrony tożsamości ruskiej przed katolicką, jezuicką propagandą. Inicjatorami powstania bractw mieli być patriarchowie wschodni. Ideologia bracka miała być zawsze antykatolicka ${ }^{50}$. Włodzimierz Antonowicz również dopatrywał się w inicjatywach patriarszych z lata osiemdziesiątych i dziewięćdziesiątych XVI w. podstaw do powołania bractw. Historyk traktował bractwa jako „moralną opozycję wiernych” przeciwko przygotowywanej unii kościelnej ${ }^{51}$. Na dominującą rolę patriarchów wschodnich przy powstawaniu bractw, zwłaszcza stauropigialnych, zwrócił również uwagę Leonid Tymoszenko ${ }^{52}$.

$\mathrm{O}$ innych przyczynach towarzyszących zakładaniu bractw pisał Eugeniusz N. Medyński. Uważał on bractwa cerkiewne za formę obrony prawosławnej społeczności Rzeczypospolitej w obliczu jej narodowego i religijnego zagrożenia. Edward Medyński koncentrował się na politycznych aspektach powoływania bractw, w mniejszym stopniu zwracając uwagę na problemy ekonomiczno-społeczne ${ }^{53}$.

W nowszej literaturze przedmiotu genezy bractw cerkiewnych upatrywano w wielu czynnikach. W gruntownym opracowaniu poświęconym dziejom bractw

\footnotetext{
49 В. Заикин, Участие светского элемента в церковном управлении, выборное начало и соборность в киевской митрополии в XVI и XVII веках, Варшава 1930, с. 49-64.

50 М. О. Коялович, Литовская церковная уния, т. I, Санкт-Петербург 1859, с. 80-108; idem, Публичные лекции о братствах, „Томские епархиальные ведомости”, № 3, Томск 1859; idem, Литовская церковная уния, т. I-II, Санкт-Петербург 1859-1861.

51 В. Б. Антонович, Об унии и состоянии православной церкви с половины XVII до кониа XVIII cm., [в:] Архив Юго-Западной России, издаваемьй временною комиссиею для разбора древних актов, высочайше учрежденною при Киевском, Подольском и Волынском генерал-губернаторе, ч. I, т. 4, Киев 1871, Введение.

52 Л. Тимошенко, Ставропігія иерковних братств у контексті Берестейської унії. Iсторіографічний аспект, [в:] Confraternitas. Україна: культурна спадщина, національна свідомість, державність, вып. 15, 2006-2007, с. 250-267.

53 Е. М. Мединський, Братские школь Украины и Белоруссии в XVI-XVII вв. и их роль в воссоединении Украины с Россией, Москова 1954; tenże, Братські школи України і Білорусії в XVI-XVII століттях, Київ 1958.
} 
cerkiewnych Jarosław Isajewicz uzasadniał, że dawne formy organizacji rodowo-terytorialnej przygotowały grunt do powołania bractw nowego typu. Na etapie ich powstawania pojawiły się bratcziny, znane na ziemiach ruskich już w XII w., cechy, gildie, patronat nad cerkwiami i monasterami, stowarzyszenia religijne działające przy Kościele katolickim. Jarosław Isajewicz wysunął na pierwszy plan genezy bractw przyczyny ekonomiczno-polityczne. Obrona interesów ekonomicznych, religijnych i etnicznych w obliczu zagrożenia ze strony ludności polskiej, wyznania katolickiego, zainspirowała prawosławną ludność ruską do tworzenia bractw cerkiewnych ${ }^{54}$. Wasyl Uljanowski zwrócił uwagę na dwa etapy działalności bractw wskazujących na ich rodowód. Pierwszy trwał do 1586 r., kiedy bractwa zajmowały się sprawami wewnętrznymi w Cerkwi: działalnością charytatywną, dbaniem o moralność duchowieństwa i wiernych, zabezpieczeniem materialnym cerkwi. Bractwa te cieszyły się poparciem hierarchii cerkiewnej. W drugim etapie w latach 1586-1596 bractwa utraciły swój cerkiewny charakter i stały się typowo społecznymi organizacjami często zwalczającymi hierarchię i działającymi niezgodnie z kanonami swojego Kościoła. Niestety, autor tego poglądu nie uzasadnił przekonywającymi dowodami ${ }^{55}$.

Współczesny badacz dziejów bractw cerkiewnych Antoni Mironowicz zwrócił uwagę na inne elementy, które legły przy powstaniu bractw. W swoje monografii o bractwach cerkiewnych w Rzeczypospolitej napisał: „Geneza tego niezwykłego fenomenu, jakim były bractwa cerkiewne w XVI-XVIII w., wynikała z wielu czynników. Na powstanie bractw istotny wpływ miały zasady ustrojowe Kościoła prawosławnego oraz jego sytuacja na ziemiach litewsko-białoruskich. Wszystkie wyżej wymienione zjawiska funkcjonujące na terenie Wielkiego Księstwa Litewskiego miały znaczący wpływ na ukształtowanie się nowego charakteru bractw cerkiewnych. Ich powstanie wynikało więc już nie tylko z ustroju cechowego miast i panujących w nich stosunków wyznaniowych, ale ze wzrostu świadomości religijnej i kulturowej ludności ruskiej" 56 .

Obecnie pogląd Antoniego Mironowicza jest uznawany przez większość badaczy zagadnienia, chociaż we współczesnych opracowaniach obserwuje się powrót do szukania genezy bractw w cechach rzemieślniczych, funkcjonujących w miastach Wielkiego Księstwa Litewskiego. Ludomir Bieńkowski szesnastowieczne bractwa uznał za zjawisko nowe ale ukształtowane z wcześniejszych wspólnotach parafialnych. W XV i XVI stuleciu przybrały one postać zinstytucjonalizowaną,

\footnotetext{
54 Я. Д. Ісаєвич, Братства та їх роль в розвитку української культури XVI-XVIII cm., Київ 1966, c. 16-22, 60; idem, Between Eastern Tradition and the Influences from the West: Confraternities in early modern Ukraine and Byelorussia, "Ricerche Slavistiche", R., 1990, vol. 37, s. 269-293.

55 В. І. Ульяновський, Історія церкви та релігійної думки в Україні, Кн. 3. Середина XV кінець XVI століття, Київ 1994. с. 215.

56 A. Mironowicz, Bractwa cerkiewne w Rzeczypospolitej, s. 15-16; idem, Geneza bractw cerkiewnych, s. 28-29; idem, Kościót prawosławny w dawnej Rzeczypospolitej, Białystok 2001, s. 43-45.
} 
wykazującą podobieństwa do cechów rzemieślniczych. Tak ukształtowane wspólnoty społeczno-religijne dbały materialnie o świątynie i duchowieństwo, prowadziły działalność oświatową i charytatywną ${ }^{57}$. Zbigniew Wójcik podkreślał, że bractwa cerkiewne łączyły w sobie cechy związków religijnych i gospodarczo-zawodowych. Zmiana sytuacji społeczno-religijnej w Rzeczypospolitej przekształcała je w organizacje wyznaniowe, reprezentujące niższe warstwy wiernych Cerkwi prawosławnej. Konfraternie cerkiewne poprzez obronę praw swego wyznania, organizację placówek oświatowych, szpitalnych, charytatywnych oraz wsparcie materialne uczestniczyły w procesie reformowania życia wewnętrznego Cerkwi prawosławnej ${ }^{58}$. Podobny pogląd na genezę powstania bractw cerkiewnych wyraziła Beata Lorens ${ }^{59}$. Badaczka zwróciła uwagę, że bractwa konsolidowały wyznawców Cerkwi prawosławnej do obrony swej wiary oraz do walki ludności ruskiej z rządzącym w miastach patrycjatem katolickim ${ }^{60}$.

$\mathrm{Na}$ inne aspekty przy omawianiu genezy bractw zwrócił uwagę Borys Floria. Znakomity rosyjski badacz dziejów prawosławia przedstawił dwa różne nurty reformatorskie, które pojawiły się w Cerkwi w XVI w. na terenie Rzeczypospolitej. Jeden był reprezentowany przez biskupów, a drugi przez elity świeckie. Biskupi poprzez starania o uzyskanie miejsc w senacie i uznanie władzy papieskiej pragnęli podnieść swój autorytet w życiu politycznym i społecznym Rzeczypospolitej. Skupiona w bractwach szlachta i mieszczaństwo opowiadały się za gruntownymi reformami wewnątrz Cerkwi i całkowicie odrzucały propagowaną przez biskupów unię kościelną. Bractwa cerkiewne, w mniemaniu współczesnego rosyjskiego historyka, to nic innego jak ruch reformatorski w Cerkwi, często o charakterze antyhierarchicznym. Bractwa były też elementem procesu zależności duchowieństwa

\footnotetext{
57 L. Bieńkowski, Organizacja Kościoła wschodniego w Polsce, s. 828-829; Por. również A. Mironowicz, Kościót prawosławny w dawnej Rzeczypospolitej, s. 43-45.

58 Z. Wójcik, Dzikie Pola w ogniu. O Kozaczyźnie w dawnej Rzeczypospolitej, Warszawa 1961, s. $65-66$.

59 B. Lorens, Gospodarczo-społeczne funkcje bractw religijnych na pograniczu etnicznym polsko-ruskim (Rusi Czerwonej) w czasach nowożytnych, [w:] Granice i pogranicza. Historia codzienności i doświadczeń, pod red. M. Liedke, J. Sadowska, J. Trynkowski, t. I, Białystok 1999, s. 27-29; idem, Bractwa cerkiewne w eparchii przemyskiej w XVII i XVIII wieku, s. 39.

60 B. Lorens, op. cit, s. 39. Podobne opinie wyrazili Juliusz Bardach i Leszek Ćwikła. Por.: J. Bardach, Bractwa cerkiewne na ziemiach ruskich Rzeczypospolitej w XVI-XVII wieku, „Kwartalnik Historyczny" 1967, R. LXXIV, z. 1, s. 77-78; L Ćwikła, Bractwa cerkiewne jako forma organizacji ludności prawosławnej na ziemiach ruskich Rzeczypospolitej w XVI-XVII wieku, „Czasy Nowożytne" 2000, t. VIII(IX), s. 120-121.
} 
od patronatu świeckich ${ }^{61}$. Podobną koncepcje na temat powstania i roli bractw w ruchu reformowania Cerkwi wyraziła Natalia Połońska-Wasilenko ${ }^{62}$.

Biorąc pod uwagę przedstawioną wyżej dyskusję w historiografii na temat genezy bractw cerkiewnych warto przywołać pogląd Antoniego Mironowicza. „Konflikty wyznaniowe w cechach i sytuacja, w jakiej znalazła się Cerkiew prawosławna, legły u podstaw powstania bractw cerkiewnych. Swoją działalnością objęły one kwestie wyznaniowe, kulturalno-oświatowe i społeczno-polityczne. Istotny wpływ na taki stan rzeczy miał rozwój ruchu reformacyjnego, przygotowywanie unii i wzrost zamożności mieszczaństwa ruskiego. Bez względu na to, jaki czynnik miał decydujące znaczenie na ukształtowanie się bractw cerkiewnych (nadanie praw magdeburskich, specyficzne stosunki wyznaniowe i społeczne w miastach Wielkiego Księstwa Litewskiego), należy zaznaczyć, że posiadały one własną ruską tradycję, której bezpośredniej analogii nie możemy znaleźć w zachodnioeuropejskich gildiach i cechach. Bractwa na ziemiach ruskich Rzeczypospolitej nie były organizacjami masowymi, lecz skupiały najaktywniejszą część społeczności prawosławnej (np. bractwo lwowskie w swej długiej historii nie liczyło jednocześnie więcej niż 50 członków). Bractwa, mimo swego nielicznego składu, w sprawach wolności religijnej i swobodnego rozwoju kultury narodowej wyrażały podstawowe interesy narodu ruskiego"63.

Pogląd ten potwierdzają informacje o pierwszych organizacjach brackich. Pierwsze bractwo cerkiewne powstało na terenie Wilna ok. $1450 \mathrm{r}$. opierając się na cechu kuśnierskim. Powodem jego powstania były stosunki panujące w wileńskich cechach rzemieślniczych. W większości cechów władze były zdominowane przez osoby wyznania rzymskokatolickiego. Pomimo formalnego równouprawnienia religijnego cechy wymagały od swych członków pewnych zobowiązań względem Kościoła łacińskiego (płacenia składek duchowieństwu, uczestniczenie w nabożeństwach katolickich). Obowiązek uczestniczenia w nabożeństwach kościelnych wszystkich członków organizacji cechowej znajdujemy w wielu statutach cechów

\footnotetext{
61 Б. Н. Флоря, Епископы, православная знать и братства. Вопрос о реформе иеркви в последние десятилетия XVI в., [в:] М. В. Дмитриев, Б. Н. Флоря, С. Г. Яковенко, Брестская уния 1596 г. и общественно-политическая борьба на Украине и в Белоруссии в конще XVI начале XVII в., ч.1. Брестская уния 1596. Исторические причины события, Отв. ред. Б. Н. Флоря; Москва 1996, с. 95-116; idem, Комментарии, [в:] Макарий (Булгаков), митр. История русской церкви, кн. 5, Москва 1996, с. 421-492; idem, Отночения государства и церкви у восточных и западных славян: (Эпоха средневековья), Москва 1992, с. 136-143, 156.

62 Н. Д. Полонська-Василенко, Братства на Україні, [в:] Н. Д. Полонська-Василенко, Минуле і сучасне, Мюнхен 1947; еаdem, Історія України, Київ 1992, с. 383, 385.

63 A. Mironowicz, Kościót prawosławny w państwie Piastów i Jagiellonów, s. 191; idem, Bractwa cerkiewne w Rzeczypospolitej, s. 15-16; idem, Geneza bractw cerkiewnych, s. 28-29;idem, Kościót prawosławny w dawnej Rzeczypospolitej, s. 43-45. Podobną opinię wyraził Jarosław Isajewicz, por.: Я. Д. Ісаєвич, Братства та їх роль, с. 60 oraz Anatol Gryckiewicz, por.: А. П. Грицкевич, Социальная борьба горожан Белоруссии в XVI-XVIII в., Минск 1979, с. 122, 123.
} 
wileńskich np. szewskim i rzeźniczym ${ }^{64}$. W niektórych cechach rzemieślniczych różnowiercy mogli uwolnić się od obowiązku uczestniczenia w nabożeństwach Kościoła katolickiego przez wniesienie odpowiednich sum w charakterze kary za nieobecność. Życie cechowe było regulowane według świąt Kościoła katolickiego. Podczas wyborów władz cechowych pierwsi głosowali katolicy, a następnie rzemieślnicy innych wyznań. Podobna sytuacja występowała przy zabieraniu głosu. Stan taki odbiegał od ducha przywileju Zygmunta Kiejstutowicza z 1432 r. nadającego mieszczanom wileńskim prawa magdeburskie i upodabniający ustrój administracyjny miasta do Krakowa. Rada miasta $\mathrm{z}$ burmistrzem była wybierana spośród mieszkańców Wilna. Do rady miejskiej mieli prawo wybierać ,połowicu zakonu rymskoho, a połowicu zakonu hreckoho" ${ }^{\circ 5}$. Liczba burmistrzów Wilna miała być równa „religii rzymskiej i greckiej”. Uprzywilejowane stanowisko rzymskich katolików w cechach rzemieślniczych zmusiło prawosławnych członków cechów do tworzenia własnych organizacji o charakterze wyznaniowym. W ten sposób powstały pierwsze bractwa cerkiewne na terenie Wilna. W ciągu XVI w. statuty cechowe respektowały zasadę równości wyznania katolickiego i prawosławia. Dla przykładu Zygmunt August w ustawie dla cechu szewskiego z 9 grudnia 1552 r. nakazywał, aby corocznie wybierano sześciu starszych po połowie z rzymskiej i greckiej wiary ${ }^{66}$. Ćwierć wieku później Stefan Batory w przywileju dla tegoż cechu dopuszcza do udziału we władzach cechowych wyznanie augsburskie utożsamiane w Wilnie z narodowością niemiecką ${ }^{67}$. Faworyzowanie katolików znajdujemy już w 1575 r. w postanowieniu braci cechu szewskiego. Postanowili oni płacić księdzu rzymskiej wiary po cztery kopy rocznie oraz dawać pieniądze na wosk oraz inne potrzeby kościoła katolickiego, zaś ,,popu wiary greckiej (...) bracia powinni dawać także z brackiej skrzynki na każdy rok po dwie kopie litewskich", a na świece lub wosk dla cerkwi św. Jana Chrzciciela każdego roku pół kamienia wosku ${ }^{68}$. Sytuacja w cechach zmieniła się za panowania Zygmunta III Wazy. W 1594 r. doszło do konfliktu w cechu szewskim między mistrzami obrządku rzymskiego i mistrzami strony ruskiej, do których dołączyli wkrótce szewcy religii niemieckiej ${ }^{69}$.

${ }^{64}$ K. Chodynicki, O stosunkach wyznaniowych w cechach wileńskich od XV do XVIII w., [w:] Księga pamiątkowa ku czci Oswalda Balzera, t. I, Lwów 1925, s. 117-131; idem, Kościót prawostawny..., s. $90-92$.

65 P. Dubiński, Zbiór praw i przywilejów miastu stołecznemu W. X. Lit. Wilnowi nadanych, Wilno 1788, s. 5; Zbiór dawnych dyplomów i aktów miast: Wilna, Kowna, Trok, prawosławnych monasterów, cerkwi w różnych sprawach, cz. II, Wilno 1843, s. 6-8; М. Грушевський, Історія України$P y c u$, т. VI, c. 526-527.

${ }^{66}$ Akty cechów wileńskich 1495-1759. Zebrat i przygotowat do druku Henryk Łowmiański przy współudziale Marii Łowmiańskiej i Stanisława Kościałkowskiego, Poznań 2006, nr 39, s. 44-46.

${ }^{67}$ Akty cechów wileńskich 1495-1759, nr 62, s. 78-83.

68 Akty cechów wileńskich 1495-1759, nr 56, s. 65-66.

69 Akty cechów wileńskich 1495-1759, nr 89, s. 107; nr 102, s. 127; nr 103, s. 128-129. 
Bractwa posiadały własne domy i rządziły się specjalnym statutem regulującym ich życie wewnętrzne. Członkowie bractwa na własny koszt wyrabiali świece, sycili miód, który był spożywany podczas wielkich świąt (Boże Narodzenie, Wielkanoc). Na czele bractw stali wybierani corocznie starostowie, którzy przy pomocy kluczników zarządzali majątkiem bractwa. Starostowie rozstrzygali spory i konflikty między członkami bractwa, sprawowali nadzór nad życiem moralnym i religijnym. Pierwsze bractwa wileńskie były więc stowarzyszeniami o celach religijno-towarzyskich, skupiającymi rzemieślników wyznania prawosławnego.

Rozwój bractw cerkiewnych nastąpił w miastach Wielkiego Księstwa Litewskiego w pierwszej połowie XVI w. Powstawaniu nowych bractw towarzyszył wzrost politycznego znaczenia mieszczaństwa w miastach posiadających prawa magdeburskie, rozwój życia religijnego, na który wpływ miała reformacja oraz upowszechnienie się kultury renesansowej. W miastach o mieszanej strukturze wyznaniowej powstawanie bractw było wywołane nie tylko potrzebami religijnymi, ale także względami społeczno-politycznymi. Posiadanie legalnej organizacji pozwalało członkom bractwa skuteczniej bronić ich świeckich interesów. Wśród społeczności brackiej rozwinął się ruch dążący do reformowania Cerkwi, a zwłaszcza do podniesienia poziomu moralnego i umysłowego duchowieństwa i wiernych.

Tendencje reformatorskie najwcześniej pojawiły się wśród prawosławnego mieszczaństwa Wilna i Lwowa. Już na początku XVI w. w Wilnie opierając się na cechu garbarskim, kupieckim i kuśnierskim powstało kilka bractw cerkiewnych ${ }^{70}$. Regulaminy nowo powstałych bractw, zwane ustawami, były podobne do statutów organizacji cechowych. Bractwa posiadały własny samorząd i same rozstrzygały sądy nad swoimi członkami. Wszyscy zobowiązani byli do wnoszenia składek i sycenia miodu w ważniejsze święta. Podobne bractwa powstały we Lwowie przy cerkwiach Objawienia Pańskiego (1542) Zwiastowania NMP, Zaśnięcia NMP, św. Mikołaja (1544) i Wiszni przy cerkwi św. Trójcy (1563) ${ }^{71}$. Bractwa zajmowały się przeważnie sprawami religijnymi i filantropijnymi. Niektóre z nich utrzymywały szpitale, opiekowały się wdowami i sierotami, udzielały kredytów zubożałym członkom, organizowały uroczystości świeckie i religijne.

Podsumowując dyskusję na temat genezy bractw cerkiewnych, trzeba zwrócić uwagę, że były one zrzeszeniami wyznaniowo-narodowymi, zorganizowanymi na zasadzie dobrowolności, skupiających ludzi świeckich i duchownych wywodzących się z różnych stanów i warstw społecznych, wyznawców Cerkwi prawosławnej. Organizacje te powstawały począwszy od XV w. na wschodnich obszarach Rzeczypospolitej. Organizacje brackie przy cerkwiach i monasterach funkcjonowały wyłącznie na terenie Rzeczypospolitej. Z tego powodu trudno jest dopatrywać się

70 W. Łuksza, W sprawie prawostawnych bractw miodowych..., s. 288.

71 М. Грушевський, Історія України-Руси, т.VI, с. 506-508; Я. Д. Ісаєвич, Братства та їх роль, с. 28. 
analogii z innymi stowarzyszeniami kościelnymi w innych krajach. Instytucji tych nie znano w innych państwach, w których mieszkańcami byli wyznawcy prawosławia. $\mathrm{Z}$ uwagi na cele i zadania prawosławnych bractw cerkiewnych nie można ich łączyć z konfraterniami unickimi czy łacińskimi. Najtrafniejszą definicję bractwa cerkiewnego przedstawiła starszyzna bractwa kijowskiego w $1625 \mathrm{r}$. w piśmie do cara moskiewskiego Michała I Fiodorowicza (1613-1645): „Bractwem się nazywa, kiedy chrześcijanie prawosławni, żyjący pośród Lachów, unitów i przeklętych heretyków, i chcąc wyłączyć się spośród nich i nie mieć z nimi nic wspólnego, sami ze sobą miłością łączą się, imiona swoje w jedno spisują i braćmi się nazywają, a tak mocniej i prędzej innowierców odeprzeć mogą"72. Powyższe wytłumaczenie pisane przez samych członków tego specyficznego stowarzyszenia wiernych wyznania prawosławnego najpełniej oddają jego genezę, istotę i charakter.

\section{A dispute about the origin of Orthodox Brotherhoods in the historical literature}

\section{Summary}

The article has discussed the issue of origin of Orthodox Brotherhoods. Historians' opinions on the origin and background of Orthodox Brotherhoods differ considerably. Some historians claimed they derived from House Brotherhoods operating in Ruthenia, others believed they were established in effect of Magdeburg Law while some connected their beginnings with craft guilds. Moreover, it was also assumed that Orthodox Brotherhoods emerged due to the attempted defence to preserve Orthodox Church in difficult religious and political conditions, or the attempted reforms of Orthodox Church in effect of the decline of Orthodox hierarchy at the end of the 16th century. The article invokes different opinions of Polish and Russian historians as well as the author's own opinion thereon.

Key words: Orthodox Church, Orthodox Brotherhoods, The Republic of Poland, religious associations, denominational relations.

\section{Bibliografia:}

Akty cechów wileńskich 1495-1759. Zebrat i przygotował do druku Henryk Łowmiański przy współudziale Marii Łowmiańskiej $i$ Stanisława Kościałkowskiego, Poznań 2006.

72 J. Bardach, op. cit., s. 77. 
Zbiór dawnych dyplomów i aktów miast: Wilna, Kowna, Trok, prawosławnych monasterów, cerkwi w różnych sprawach, cz. II, Wilno 1843.

Bartoszewicz J., Szkic dziejów kościoła ruskiego w Polsce, Kraków 1880.

Bardach J., Bractwa cerkiewne na ziemiach ruskich Rzeczypospolitej w XVI-XVII wieku, „Kwartalnik Historyczny” 1967, R. LXXIV, z. 1.

Bieńkowski L., Organizacja Kościoła wschodniego w Polsce, [w:] Kościół w Polsce. Studia nad historią Kościoła Katolickiego w Polsce, red. J. Kłoczowski, t. II, cz. 2, Kraków 1969.

Chodynicki K., Kościół prawosławny a Rzeczpospolita Polska. Zarys historyczny 1370_ 1632, Warszawa 1934.

Chodynicki K., O stosunkach wyznaniowych w cechach wileńskich od XV do XVIII w., [w:] Księga pamiątkowa ku czci Oswalda Balzera, t. I, Lwów 1925.

Ćwikła L., Bractwa cerkiewne jako forma organizacji ludności prawosławnej na ziemiach ruskich Rzeczypospolitej w XVI-XVII wieku, „Czasy Nowożytne” 2000, t. VIII(IX).

Dmitruk S., Teorie naukowe dotyczące powstania bractw cerkiewnych na terenie Rzeczypospolitej Obojga Narodów w XV-XVI wieku, „Wschód Europy” 2015, nr 1(2).

Dubiński P., Zbiór praw i przywilejów miastu stołecznemu W. X. Lit. Wilnowi nadanych, Wilno 1788.

Kłoczowski J., Wspólnoty chrześcijańskie. Grupy życia wspólnego w chrześcijaństwie zachodnim od starożytności do XV w., Warszawa 1964.

Kumor B., Kościelne stowarzyszenia świeckich na ziemiach polskich w okresie przedrozbiorowym, „Prawo Kanoniczne” 1967, t. X, nr 1-2.

Kuźmiak K., Szegda M., Cerkiewne bractwo, [w:] Encyklopedia Katolicka, t. III, Lublin 1985, szp. 13-14.

Litak S., Bractwa religijne w Polsce przedrozbiorowej XIII-XVIII wiek. Rozwój i problematyka, „Przegląd Historyczny” 1997, t. 88, z. 3-4.

Likowski E., Unia brzeska (r. 1596), Poznań 1896.

Lorens B., Bractwa cerkiewne w eparchii przemyskiej w XVII i XVIII wieku, Rzeszów 2005.

Lorens B., Gospodarczo-społeczne funkcje bractw religijnych na pograniczu etnicznym polsko-ruskim (Rusi Czerwonej) w czasach nowożytnych, [w:] Granice i pogranicza. Historia codzienności i doświadczeń, red. M. Liedke, J. Sadowska, J. Trynkowski, t. I, Białystok 1999.

Łuksza W., W sprawie prawosławnych bractw miodowych $w$ Wilnie, „Atheneum Wileńskie" 1938, t. XIII, z. 2.

Mironowicz A., Bractwa cerkiewne w Rzeczypospolitej, Białystok 2003.

Mironowicz A., Geneza bractw cerkiewnych, „Białoruskie Zeszyty Historyczne” 1996, nr 2 (6).

Mironowicz A., Kościót prawosławny w dawnej Rzeczypospolitej, Białystok 2001.

Mironowicz A., Kościót prawosławny w państwie Piastów i Jagiellonów, Białystok 2003. 
Morzy J., Geneza i rozwój cechów wileńskich do końca XVII w., „Zeszyty Naukowe Uniwersytetu Adama Mickiewicza”, Seria Historia, z. IV, Poznań 1959.

Opoka M., Prawosławne bractwa na Rusi, „Oriens” 1938, R. VI.

Podraza A., Dzieje ziem ukraińskich do 1569 r., [w:] Ukraina. Teraźniejszość i przeszłość, red. A. Podraza, Kraków 1970.

Ptaśnik J., Miasta i mieszczaństwo w dawnej Polsce, Warszawa 1949.

Samsonowicz H., Mieszczaństwo Rzeczypospolitej wobec Unii Brzeskiej, [w:] Unia brzeska z perspektywy czterech stuleci, red. J. S. Gajek, S. Nabywaniec, Lublin 1998.

Szaraniewicz I., Kościelna Unia na Rusi i wpływ jej na zmianę stanowiska społecznego świeckiego duchowieństwa ruskiego, [w:] Księga pamiątkowa drugiego Wiecu Katolickiego odbytego we Lwowie w dniach 7, 8 i 9 lipca 1896 roku. Część I, Lwów 1899.

Szaraniewicz I., Patryjarchat wschodni wobec Kościoła ruskiego i Rzeczypospolitej Polskiej, Lwów 1879.

Wipszycka E., Świeckie bractwa w życiu religijnym chrześcijańskiego Egiptu, „Przegląd Historyczny" 1968, R. LIX, z. 3.

Woliński J., Polska i Kościót prawosławny. Zarys historyczny, Lwów 1936.

Wójcik Z., Dzikie Pola w ogniu. O Kozaczyźnie w dawnej Rzeczypospolitej, Warszawa 1961.

Антонович В. Б., Об унии и состоянии православной иеркви с половины XVII до кониа XVIII cm., [в:] Архив Юго-Западной России, издаваемысй временною комиссиею для разбора древних актов, высочайше учрежденною при Киевском, Подольском и Волынском генерал-губернаторе, ч. I, т. 4, Киев 1871, Введение.

Великжанин Д. А., Религиозно-оборонительные братства Украины о Белоруссии кониа XVI - первой половины XVII вв. как институты православной иеркви, „Научные проблемы гуманитарных исследований”, №9, 2010.

Голубев С. Т., История Киевской Духовной Академии, вып. 1: Период до-могилянский, Киев 1886.

Голубев С. Т., О первых временах Киево-Богоявленского братства и школь при нем, „Труды Киевской Духовной Академии”, № 3, 1882.

Грицкевич А. П., Социальная борьба горожан Белоруссии в XVI-XVIII в., Минск 1979.

Грушевський М., Історія України-Руси, т. VI: Житє економічне, культурне, національне XIV-XVII віків, Київ-Львів, 1907.

Грушевський М., Історія украӥнської літератури, Київ, 1995, т. V, кн. 2.

Гудзяк Б., Киевская иерархия, Константинопольский патриархат и уния с Римом, [в:] 400 лет Брестской иерковной унии (1596-1996): Критическая переоценка. Сборник материалов международного симпозиума. Неймеген, Голландия, Москва 1998. 
Гудзяк Б., Кониепиії унії в иерковних і державних колах Речі Посполитої кіния XVI cm., [в:] Історичний контекст укладення унії і перше поунійне покоління: Матеріали Перших Берестейських читань, Львів 1995.

Гудзяк Б., Царгородський патріархат у кіниі XVI ст.: криза і спроби реборм, [в:] Пробф деміка Ярослава Ісаєвича, Укл. Б. Якимович, Львів 1998.

Дмитриев М. В., Концепиії унії в церковних і державних колах Речі Посполитої кіния XVI cm., [в:] Історичний контекст укладення унї і перше поунійне покоління: Матеріали Перших Берестейських читань, Львів 1995

Дмитриев М. В., Между Римом и Царьградом: генезис Брестской иерковной унии 1595-1596 г2., Москва 2003.

Дмитриев М. В., Религиозно-культурная и социальная программа греко-католической иеркви в Речи Посполитой в конце XVI первой половине XVII в., [в:] Славяне и их соседи. Католииизм и православие в Средние века, Москва 1991.

Дорофеев Ф. А., Православные братства: генезис, эволюиия, современное состояние, Нижний Новгород 2006.

Ефименко А. Я., Южно-русские церковные братства, „Слово” 1880, нр. 10-12.

Ефименко А. Я., Южно-русские братства, [в:] Южная Русь (Очерки, исследования, заметки), т. I, Санкт-Петербург 1905.

Ефименко П., Братства и союзы нищих, „Киевская старина”, т. VII, Киев 1883, нр. 9. Жудро Ф., История Могилевского Богоявленского братства, Могилев 1890.

Заикин В., Участие светского элемента в церковном управлении, выборное начало и соборность в киевской митрополии в XVI и XVII веках, Варшава 1930.

Ісаєвич Я. Д., Братства та їх роль в розвитку украӥнської культури XVI-XVIII cm., Київ 1966.

Коялович М. О., Литовская церковная уния, т. I, Санкт-Петербург 1859.

Коялович М. О., Публичные лекиии о братствах, „Томские епархиальные ведомости”, № 3, Томск 1859.

Коялович М. О., Чтение о иерковных западнорусских братствах, „День”, 1862, № 36, с. 5 ; № $37-42$.

Левицкий О. И., Внутреннее состояние западно-русской церкви в польско-литовском государстве в коние XVI в. и уния, Киев 1884.

Левицкий О. И., Социнианство в Польше и Юго-Западной Руси [в:] „Киевская Старина”, т. II, 1882.

Лотоцький А., Украінські джерела церковного права, Варшава 1931.

Лукашова С. С., Движение православных братств на украинско-белорусских землях в последней четверти XVI в., [в:] Тезисы доклада на V Международном конгрессе украинистов, Черновцы 2002.

Лукашова С. С., Миряне и Церковь: религиозные братства киевской митрополии в коние XVI в., Москова 2006. 
Лукашова С. С., Мифы и стереотипь в историографии украинско-белорусских братств XVI-XVII вв. [в:] Между Москвой, Киевом и Варшавой, Москва 2008.

Луців В., Церковні братства в Украӥні, „Богословия”, Рим 1973.

Макарий (Булгаков), митр., История Русской Церкви, т. IX, кн. 4, Санкт-Петербург 1879.

Мединський Е. М., Братские школь Украины и Белоруссии в XVI-XVII вв. и их роль в воссоединении Украины с Россией, Москова 1954.

Мединський Е. М., Братські школи України і Білорусії в XVI-XVII століттях, Київ 1958.

Новицкая-Ежова А., Орден базилиан и его культурно-просветительская деятельность на украино-белорусско-литовских землях Речи Посполитой, „Славяноведение”, № 2, 1996.

Папков А. А., Братства как мощная защита Православия - вплоть до восстановления православной иерархии в 1620 году (1600-1620), [в:] „Богословский вестник”, - январь, Сергиев Посад 1898

Папков А. А., Братства. Очерки истории западно-русских православных братств, Сергиев Посад 1900.

Папков А. А., Древнерусский приход, „Богословский вестник”, ч. III, № 2. - Сергиев Посад 1897.

Папков А. А., Начало возрождения иерковно-приходскойжизни в России, Отдельный оттиск из журнала “Русский Вестник”, Москва 1900.

Папков А. А., Церковные братства. Краткий статистический очерк о положении иерковных братств к началу 1893 года, Санкт-Петербург 1893.

Плохий С. Н., Папство и Украина: политика римской курии на украинских землях в XVI-XVII вв. Киев 1989.

Покровский М. Н., Русская история с древнейших времен, т. II, Москва 1926.

Полонська-Василенко Н. Д., Братства на Україні, [в:] Н. Д. Полонська-Василенко, Минуле і сучасне, Мюнхен 1947.

Полонська-Василенко Н. Д., Історія України, Київ 1992.

Сенык С., Брестская уния: подведение итогов, [в:] 400 тет Брестской иерковной унии (1596-1996): Критическая переоценка: Сборник материалов международного симпозиума, Неймеген, Голландия, Москва 1998.

Скабаланович Н., Западно-Европейские гильдии и западно-русские братства, „Христианское чтение", ч. II, 1875

Соловьев С. М., Братчины, „Русская беседа”, кн. IV, 1856.

Суворов Н. С., Учебник иерковного права, Москва 1913.

Тимошенко Л., Ставропігія иерковних братств у контексті Берестейської унії. Iсторіографічний аспект, [в:] Confraternitas. Україна: культурна спадщина, національна свідомість, державність, вып. 15, 2006-2007. 
Ульяновський В. І., Історія иеркви та релігійної думки в Украӥні, Кн. 3. Середина XV кінець XVI століття, Київ 1994.

Фефелова О. А., Исторические источники по истории православных братств на территории Беларуси во второй половине XVI - первой половине XVII века, „Вестник ТГПУ”, 2010, Вып. 9 (99).

Фефелова О. А., Православные братства на восточнославянских территориях Речи Посполитой во второй половине XVI - первой половине XVII веков, Оглавление научной работы автор диссертации - кандидата исторических наук Фефелова Оксана Анатольевна, Томск 2001.

Фіголь В., Церковні братства галицької греко-католицької провінції у XVIII cm., „Богословія”, т. XV, Рим 1937.

Флеров И. О., О православных иеерковных братствах, противодействовавших унии в Юго-Западной России в XVI, XVII и XVIII cm., Санкт-Петербург 1857.

Флоря Б. Н., Епископь, православная знать и братства. Вопрос о реборме иеркви в последние десятилетия XVI в., [в:] М. В. Дмитриев, Б. Н. Флоря, С. Г. Яковенко, Брестская уния 1596 г. и общественно-политическая борьба на Украине и в Белоруссии в конце XVI начале XVII в., ч.1. Брестская уния 1596. Исторические причины события, Отв. ред. Б. Н. Флоря; Москва 1996.

Шустова Ю. Э., Типология происхождения братств Украины, [в:] Историко-филологический вестник Украинского Института, т. I, Москва 1997.

Шустова Ю. Э., Украӥнські братства як провідники діяльної релігійності в кінці XVI і на початку XVII cm., [в:] Історія релігій в Україні: Матеріали VIII міжнародного круглого столу, Львів 1998.

Яковенко С. Г., Православная иерархия Речи Посполитой и планы иерковной унии в 1590-1594 г2. [в:] „Славяне и их соседи”, вып. 3, Католииизм и православие в средние века, Москва 1991.

Ісаєвич Я. Д., Between Eastern Tradition and the Influences from the West: Confraternities in early modern Ukraine and Byelorussia, "Ricerche Slavistiche" 1990, vol. 37. 